\title{
Analysis of Qualitative Studies of the Use of Ict in Learning Environments
}

\author{
Marisol Esperanza Cipagauta Moyano ${ }^{1}$, Adriana Quimbayo Feria, ${ }^{2,}$ Adriana Castro Camelo ${ }^{3}$ \\ ${ }^{1}$ Corporación Universitaria Minuto de Dios-UNIMINUTO, Bogotá, Colombia. Professor at \\ Master in Education. \\ ${ }^{2}$ Corporación Universitaria Minuto de Dios-UNIMINUTO, Bogotá, Colombia. Professor at \\ Master in Education.(Corresponding author) \\ ${ }^{3}$ Corporación Universitaria Minuto de Dios-UNIMINUTO, Bogotá, Colombia. Professor at \\ Master in Education.
}

\section{ARTICLE INFO}

Keywords:

education, teaching;

digital; context; impact.

\begin{abstract}
This paper analyzes the qualitative methodological approaches used by the students of the Master's Degree in Education during the years 2017, 2018 and 2019 from the Research Project entitled: Use of ICT in learning environments. For this analysis, it is reviewed the scope of research that incorporates the use of information and communication technologies in different educational contexts, in which students develop their research as a degree option to qualify for the Master's Degree. It is also made a selection of the works that use the qualitative methodology in order to determine the designs and methods they use to achieve the objectives proposed in the Research. From this analysis, it is made a reading that allows to investigate new areas of study in the field of education, as well as other ways of approaching the use of ICT in a world where digital prevails and education is no stranger to these changes and evolution that is constantly taking place, which facilitates having recent data on the subject and the impact on the educational act.
\end{abstract}

\section{Introduction}

\subsection{Role of the teacher in the teaching-learning process}

To talk about ICT in education, it is important to analyze the role that the teacher plays in the digital world, taking into account that, some time ago, the teacher was considered as the one who possessed all the information and knowledge and their role was limited to being a transmitter of this; nowadays with the incursion of technology, social crises, the role of knowledge, population mobility and migration -where education becomes a hope of personal improvement and contribution to economic growth (Boltanski and Chiapello, 2002; Chesbrough, 2015; González \& Ospina, 2015; López, 2008)- the concept of the teacher has changed considerably and has led university professors to assume not only the role of producers and reproducers of knowledge, but

\footnotetext{
$\square$ Corresponding Author E-Mail Address: mcipagauta@uniminuto.edu
} 
also the role of facing the socialization of the academic community through interdisciplinary networks and relationships; they are also guides in comprehensive training, regional integration, dissemination and creation of values, mediation to create a critical awareness and have the ability to solve problems and to train in new pedagogical approaches and work tensions between theory and practice in his work, as López (2008, p. 15) explains for Latin America and in particular for Colombia. It means that, from being transmitters, the teacher becomes a mediator of the process in the use of ICT (Núñez, Gaviria-Serrano, Tobón, Guzmán-Calderón and Herrera, 2019; Pozos Pérez and Tejada Fernández, 2018) and in this process, the teacher not only guides his students but also learns and accompanies them.

In this digital age, today's teachers face challenges that they did not have before or at least not with such force, these challenges can be seen at different times of their practice as explained by Pozos and Tejada (2018) when recognize the necessary skills for planning and designing learning experiences at face-to-face and/or virtual environments; the development and conduction of face-to-face and/or network collaborative learning experiences; the orientation, guidance and evaluation of the students' knowledge construction processes in face-to-face and/or virtual environments; student growth management and professional development with ICT support; and in research, development and pedagogical innovation with ICT and for the use of ICT in education; on issues of diversity, ethics and responsible use of ICT's in teacher professional performance; and respect for the environment, health and safety at work with the use of ICT in the teaching profession (Pozos Pérez \& Tejada Fernández, 2018, pp. 24-29), competencies that are for the teacher as well and that they must assume in their permanent training.

According to Tébar (2016), the teacher has to become an architect, builder, bridge, motor, transformer, adapter, amplifier, coach, philosopher, therapist, guide, manager, pitcher, compass, chef, doctor, Samaritan, director and actor, professions that, together with that of the teacher, exercise directly or indirectly in the development of the teaching-learning process.

Although in the dynamics of education and training, there are courses or programs where the figure of the teacher does not exist; it means, there is no teacher to guide the process because they are courses based on self-learning like the mooc $^{1}$, in this case, the teacher has done a previous job and is the design of course content and to carry out research on different aspects: the language for the web, the type of activities, navigability, access to resources, the same physical resources available or in line, the interface, the user experience, in this way the teacher is the protagonist.

As for the investigation of his own classroom practice, the teacher evaluates his pedagogical work and from the results, he designs improvements in favor of the quality of his own performance, which results in the strengthening of his work as a teacher. "The quality of a university educational institution depends fundamentally on the human, pedagogical and scientific quality of its teachers, that is why it has been a constant concern of universities to prepare and train their teachers" (Castillo, 2017, p. 67) that is why it is important to train teachers permanently.

However, this is not only about the accompaniment of teachers to students, but that he has a commitment to the evaluation of his learning process (Núñez et al., 2019), in which he feeds the work indicating strengths, weaknesses and areas of improvement, not simply assigning a rating. In this aspect, the teacher's role is complemented by the evaluation process that performs and analyzes

\footnotetext{
${ }^{1}$ The so-called MOOCs (Massive Open Online Course) are an online training modality characterized by being massive and open online courses, that is, designed to be taught to a large number of students.
} 
elements such as goals, roles, activities, resources, among other elements (Aguiar, Velázquez, \& Aguiar, 2019).

There is also another important aspect to take into account, it is the role of the teacher as an innovative pedagogical, in which it is required to be in continuous training on educational trends, teaching methodology, evaluation strategies, research management and aspects related to the internationalization of the curriculum that will let the teacher to share his knowledge with others and enrich himself through collaborative work with others. "The last key and "fundamental" process of teaching and learning is evaluation and innovation: the evaluation of what has been done, and then the search for ways to improve it" (Bates, p. 425).

\subsection{Pedagogical innovation vs. Educational innovation}

Another aspect to highlight when referring to the use of ICT in education is related to the issues about pedagogical innovation and educational innovation and their differences. Pedagogical innovation is a set of actions aimed at improving the teaching, learning and evaluation process through the use of disruptive, non-traditional teaching strategies that may or may not incorporate technology. Pedagogical innovation can be given on its own initiative or on the initiative of training centers that seek to improve their processes in educational quality. For innovation to be meaningful, it must generate some kind of impact on student learning, a fundamental actor for the implementation of innovation and of course in its immediate context. As Cobo (2016) says: "the most structural change is not related only to thinking about educators from a new perspective. It also involves thinking of trainers who are much more than technology facilitators" (p. 19).

On one hand, Educational innovation contemplates different dimensions (Aguiar et al., 2019). From the didactic it is intended to carry out actions that facilitate the use of techniques and from these, to design the curricular contents. From the social point of view, educational innovation establishes the relations of the pedagogical components in order to articulate them and that fully fulfill their purpose of reinventing the teaching, learning and evaluation process. From the cultural point of view, educational innovation is seen as an opportunity to join forces between different disciplines and consolidate inter and trans-disciplinary work. And finally, a technological dimension, innovation can have an added value, since it incorporates digital tools to be implemented and this makes it more attractive.

On the other hand, the concepts related to Educational innovations are varied: The idea: this concept is relevant because it becomes the materialization of thought, from an innovative idea an innovation can arise; The collaboration, in itself, the teamwork, the innovations involved in the competition of several actors, although someone comes up with the initial idea, the development requires a joint work; The creativity, it is born from the imagination of curious and restless people, specifically by innovating; The disruption, which is to break with the traditional, to do different things that seek solutions to both simple and complex problems; The evaluation, that more than the innovation itself, is the impact that it can cause or the solution it can offer.

In the words of Cañal de León (2002)

In the educational field, innovation can be understood, from a broad perspective, as a synonym for "pedagogical renewal". Educational innovation refers to a "set of ideas, processes and strategies, more or less systematized, through which it is about introducing and provoking changes in current educational practices." In addition, educational 
innovation is associated with change and has a component - explicit or hidden - ideological, cognitive, ethical and effective. As planned, deliberate and intentional change, proposals for pedagogical innovation arise in temporal contexts and have their own genesis and evolution. (p.11)

The previous affirmation gets clear that innovating not only means changes by themselves but they are structural changes related to the needs that can be established according to some ideas referring to teacher training, especially as regards which refers to the knowledge, skills and attitudes to carry out processes of teaching innovation.

In this sense, educational innovation nowadays, should strengthen the pedagogical development of teachers and students. Education is the conquest of wisdom and this is reflected in the innovations in the school related to the teaching methods used. This makes learning and teaching activities more active, breaking with very rigid and passive forms, which will make the student a pleasant and conducive environment for learning that is also closely related to the different learning styles, that is, to the forms that students prefer to process and organize information and respond to environmental stimuli.

Finally, it is important to highlight the differences between educational innovation and pedagogical innovation. Educational innovation includes all the processes inherent to the agents of the education system, that is, teachers, managers, students, the external sector, providers; while pedagogical innovation focuses on the teaching, learning and evaluation process. Both educational innovation and pedagogical innovation are committed to improving educational quality from any perspective. Regarding innovation in a study carried out in 2016 by the Telefónica Foundation, it is affirmed: "the innovative proposals that get to involve their students know their thought, behavior and communication patterns very well. They develop activities from the cultural coordinates of children and young people that, without a doubt, are very much in line with the digital universe. They do a user-centered design exercise that facilitates connection with their audience" (p. 20).

In this sense, and according to the challenges that the teacher must meet in the training process, the results of the students must be analyzed to recognize the progress and trends that allow the teacher to both: recognize their achievements in the process, and identify possible routes of action for the professional development demanded by the 21 st century.

That is why the analysis of the degree works that this document presents, shows both educational innovations and pedagogical innovations that are shown in the results section, where it is evident how the incorporation of ICT has impacted the teaching, learning and evaluation process in the context of the Master in Education of Virtual and Distance Uniminuto, where the 25 analyzed projects were carried out that, in addition to being approved for the granting of the degree, for the same characteristics of the institutions were carried out in different places and Colombian contexts, responding to the impact challenge argued by the literature review.

\section{Methodology}

In order to analyze the results, and to recognize the Pedagogical innovations and the Educational innovations of the works, the researchers decided to analyze the qualitative methodological approaches used by the students of the Master in Education during the years 20172019 from the research project entitled "Use of the ICT in learning environments". It is carried out 
a descriptive analysis of the hermeneutic approach of the degree works linked to this project based on the data provided by the research leader of the program for a total of 25 works, which were analyzed using the Excel Software. This analysis makes it possible to identify the patterns of qualitative methodological approaches to define from there the research trends in the use of ICTs linked to the project. This method has been used in various bibliometric analyzes reported in international literature (Fong, Flores \& Cardoza, 2017).

The first part of the research work consisted in describing the research project and its implications, as well as the evolution it has had over time. This paper analyzes the topics addressed, the social actors, the purposes, the research objective, the supporting theories, the methodologies, the results, the conclusions and impacts generated, in order to establish the current status of the research project. The choice of this methodological strategy is due to the fact that it allows a general understanding of the fields of knowledge addressed, the main users, the intentionality of the research interests, the proposed and pending goals, the literature on which the academic discussion is supported, the methods and mainly used designs, the scope and the results obtained, evidencing gaps and new requirements for future research. These criteria were selected because they allow homogeneity in the analysis as criteria required by the Master of Education program, for acceptance as undergraduate work.

This type of results will allow project leaders, as well as future researchers of the subject, to rely on the progress made to analyze, expand, or improve the research carried out, building a body of knowledge and documenting the implementation of the research project as Soriano and Pinillos (2002) affirm.

For the construction of the database in Excel, information was taken directly from the degree works stored in the "Thesis Depot" of Virtual and Distance UNIMINUTO (UVD in its initials in Spanish), once the information was organized, it was tabulated directly in the Excel matrix in order to categorize them and make simple counts of the results. These categories were defined from the existing literature in the field of knowledge.

The matrix is presented in the Image 1. It is relevant to say that data in the matrix is written in Spanish due to this is the students and authors mother tongue. 
Image 1. Characterization Matrix

\begin{tabular}{|c|c|c|c|c|c|c|c|c|c|}
\hline & $\begin{array}{l}\text { Temática } \\
\text { Abordada }\end{array}$ & $\begin{array}{l}\text { Actores } \\
\text { Sociales }\end{array}$ & Propósitos & Objetivo General & $\begin{array}{c}\text { Teorias De } \\
\text { Apovo }\end{array}$ & Metodologia & Resultados & Conclusiones & $\begin{array}{l}\text { Impacto } \\
\text { Generado }\end{array}$ \\
\hline $\begin{array}{c}\text { Arenas } \\
\text { Madroñero } \\
\text { Cindy } \\
\text { Esmeralda }\end{array}$ & $\begin{array}{l}\text { Los Estilos de } \\
\text { Aprendizaje y } \\
\text { su celacion con } \\
\text { el Aprendizaje } \\
\text { Colaborativo en } \\
\text { cursos virtuales }\end{array}$ & $\begin{array}{l}\text { Rubiela, } \\
\text { Maria } \\
\text { Fernanda, } \\
\text { Daniel } \\
\text { Rosinaa } \\
\text { Tamez } \\
\text { Almaguer } \\
\text { Dr. Armando } \\
\text { Lozano } \\
\text { Rodriguez. } \\
\text { Calvani.Fini } \\
\text { Moline y } \\
\text { Raniera } \\
\text { Lozano y } \\
\text { Tijerina } \\
\text { Romero, } \\
\text { Salinas y } \\
\text { Mortera }\end{array}$ & $\begin{array}{l}\text { 1. Identificar los estilos de } \\
\text { aprendizaje en los } \\
\text { estudiantes de acuerdo con } \\
\text { la teoria de Kallb. } \\
\text { 2. Describir las } \\
\text { caracteristicas de los estilos } \\
\text { de aprendizaje en ambientes } \\
\text { virtuales y mediante el } \\
\text { aprendizaje colaborativo. } \\
\text { 3. Determinar la relación } \\
\text { entre los estilos de } \\
\text { aprendizaje y el éxito del } \\
\text { aprendizaje colaborativo en } \\
\text { ambientes virtuales de } \\
\text { aprendizaje. } \\
\text { 4. Reconocer las estrategias } \\
\text { de enseñanza aprendizaje } \\
\text { que son más efectivas y } \\
\text { relacionan los estilos de } \\
\text { aprendizaje y el aprendizaje } \\
\text { colaborativo. }\end{array}$ & $\begin{array}{l}\text { Establecer la relación } \\
\text { entre los estilos } \\
\text { de aprendizaje } \\
\text { de acuerdo con la teoría de } \\
\text { Koltby el aprendizaje colabor } \\
\text { ativo en ambientes virtuales } \\
\text { de aprendizaje }\end{array}$ & $\begin{array}{l}\text { En el marco de } \\
\text { esta investigación, } \\
\text { se tendrá en cuenta } \\
\text { la Teoria del } \\
\text { Desarrollo } \\
\text { Experiencial o } \\
\text { Modelo de Kollb, el } \\
\text { cual permite } \\
\text { determinar la } \\
\text { caracterización de } \\
\text { los estilios de } \\
\text { aprendizaje de los } \\
\text { estudiantes que } \\
\text { serán el objeto de } \\
\text { esta investigación. }\end{array}$ & $\begin{array}{l}\text { Se selecciiona } \\
\text { un grupo de } \\
\text { estudiantes a } \\
\text { los cuales bajo } \\
\text { modalidad } \\
\text { virtual se les } \\
\text { realizó el } \\
\text { cuestionarioded } \\
\text { estilos de } \\
\text { aprendizaje de } \\
\text { Kolb ya que la } \\
\text { información } \\
\text { acerca del } \\
\text { método } \\
\text { dominante en } \\
\text { cada } \\
\text { estudiante } \\
\text { quedaba } \\
\text { almacenada, } \\
\text { Seguido a ello } \\
\text { se realizaron } \\
\text { diferentes } \\
\text { actividades } \\
\text { formando } \\
\text { equipos de } \\
\text { trabajo } \\
\text { teniendo en } \\
\text { cuenta los } \\
\text { estilos de } \\
\text { aorendizaie }\end{array}$ & $\begin{array}{l}\text { Los estilos de } \\
\text { aprendizaje } \\
\text { relacionados } \\
\text { con el } \\
\text { aprendizaje } \\
\text { colaborativo, } \\
\text { influye mucho } \\
\text { en el } \\
\text { desempeño } \\
\text { individual y } \\
\text { grupal de los } \\
\text { estudiantes, } \\
\text { conocer las } \\
\text { caracteristicas } \\
\text { de cada estilo, } \\
\text { de forma que } \\
\text { se permita } \\
\text { conformar } \\
\text { equipos de } \\
\text { trabajo más } \\
\text { afines, evitar } \\
\text { la } \\
\text { conformación } \\
\text { de equipos con } \\
\text { conductas } \\
\text { apáticas, } \\
\text { asociables y } \\
\text { herméticas, } \\
\text { como } \\
\text { asimiladores v }\end{array}$ & $\begin{array}{l}\text { el reconocimiento } \\
\text { de aspectos } \\
\text { positivos en las } \\
\text { caracteristicas del } \\
\text { estilo de } \\
\text { aprendizaje por } \\
\text { parte de los } \\
\text { estudiantes, ya que } \\
\text { les permite ser más } \\
\text { productivos en los } \\
\text { procesos de } \\
\text { aprendizaje } \\
\text { colaborativo, } \\
\text { generando así } \\
\text { mayor influencia en } \\
\text { sus compañeros, } \\
\text { mejorando y } \\
\text { potenciando el } \\
\text { desempeño } \\
\text { individual y grupal, } \\
\text { convirtiendose en } \\
\text { una estrategia } \\
\text { significativa para } \\
\text { los ambientes } \\
\text { virtuales de } \\
\text { aprendizaje, } \\
\text { benefíiando } \\
\text { además el uso de } \\
\text { herramientas } \\
\text { tecnológicas v }\end{array}$ & $\begin{array}{l}\text { 1. El estudio } \\
\text { deja un } \\
\text { precedente } \\
\text { positivo para } \\
\text { la } \\
\text { metodología } \\
\text { virtual de la } \\
\text { institución en } \\
\text { que se } \\
\text { aplicó, ya } \\
\text { que aporta } \\
\text { significativam } \\
\text { ente } \\
\text { estrategias } \\
\text { para la } \\
\text { conformación } \\
\text { de equipos } \\
\text { en } \\
\text { actividades } \\
\text { de } \\
\text { aprendizaje } \\
\text { colaborativo. } \\
\text { 2. genera } \\
\text { una } \\
\text { expectativa } \\
\text { en la } \\
\text { metodología } \\
\text { virtual en la } \\
\text { explotación }\end{array}$ \\
\hline
\end{tabular}

Font: The authors

The degree works approved by the different statutes defined by the Master in Education program were the unit of analysis used for this research, having into account that they have been reviewed and evaluated by jurors, this allowed data to be taken directly from each project. Different categories were taken to analyze the information; namely: i) Thematic: taken from the title of each project, ii) Social actors: the subjects and educational institutions that participated in the projects, iii) Purposes: the specific objectives of the research, iv) Supporting theories: built from the theoretical references selected by the authors mentioned in the development of each research work, v) Methodologies: recorded according to the guidelines of the methodology chapter, vi) Results: taken from the findings described in the analysis of the results of the research chapter; and finally, vii) Conclusions and impacts generated: taken from the conclusions and recommendations chapter in each work.

\section{Results}

Regarding the results obtained in the use of methodological approaches, they respond to see that the most used techniques are the survey carried out through the use of technologies and complemented with interviews that were conducted combining face-to-face and virtual appointments according to availability and geographical location of the interviewees. These techniques were complemented with some face-to-face ones such as participant observation and case studies. There is also the presence of focus groups, which demonstrates the importance of collective learning as recognized in the literature review. In general, they are qualitative techniques that collect data through the selected instruments to proceed with the corresponding interpretation and analysis of the results gained, which allows the researcher to propose routes to improve or strengthen the problem posed. This is a sample of pedagogical innovations in this area due to these techniques approach on the teaching, learning and evaluation process. The summary is presented in Figure 1. 


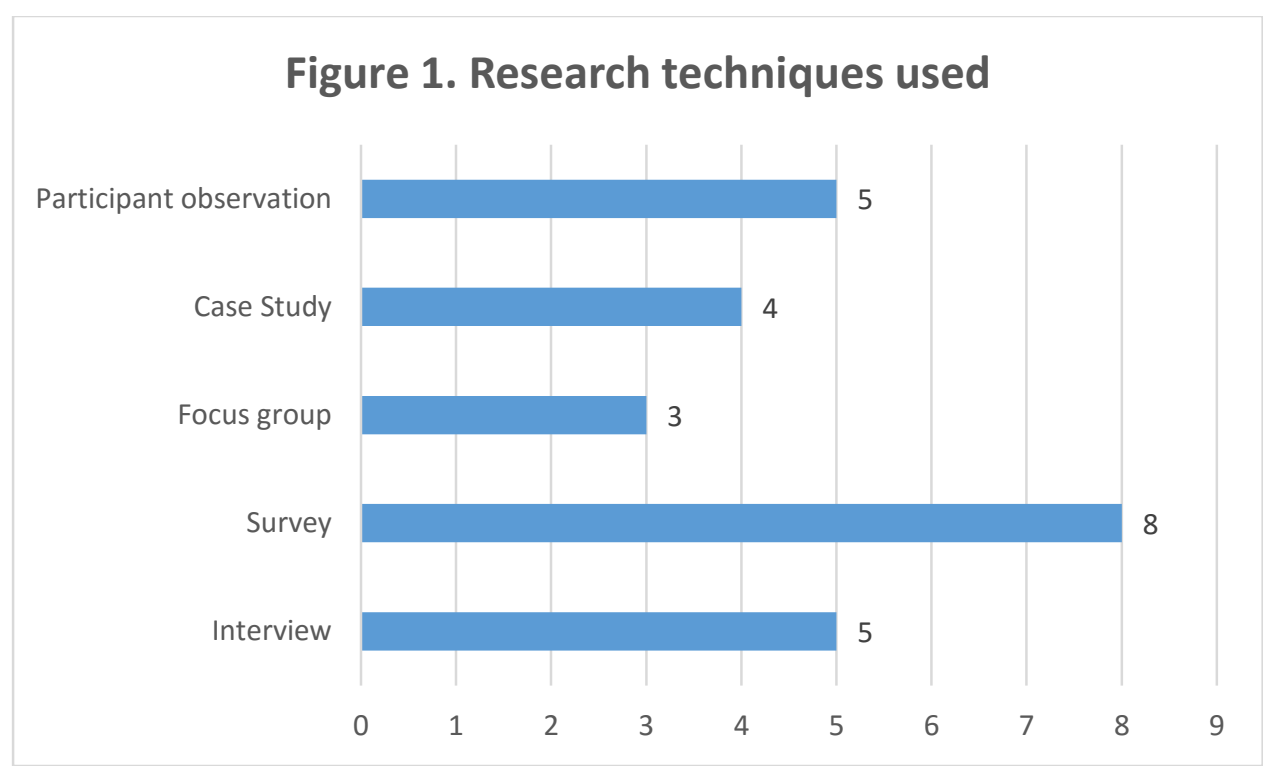

Font: The authors

Related to the research topics, the priority is the use of virtual platforms (for a difference of double compared to other topic). Secondly, it is the teachers' digital competencies and the selfregulation of learning using ICT, each with a frequency of 4 works. This reflects that young people are investigating the challenges that social change demands from the academy as López argued since 2008 and as seen in the orientations of some recent publications in education. This is a sample of Educational innovations due to the research topics include some processes inherent to the teachers, students and external sector providers. The summary is seen in figure 2.

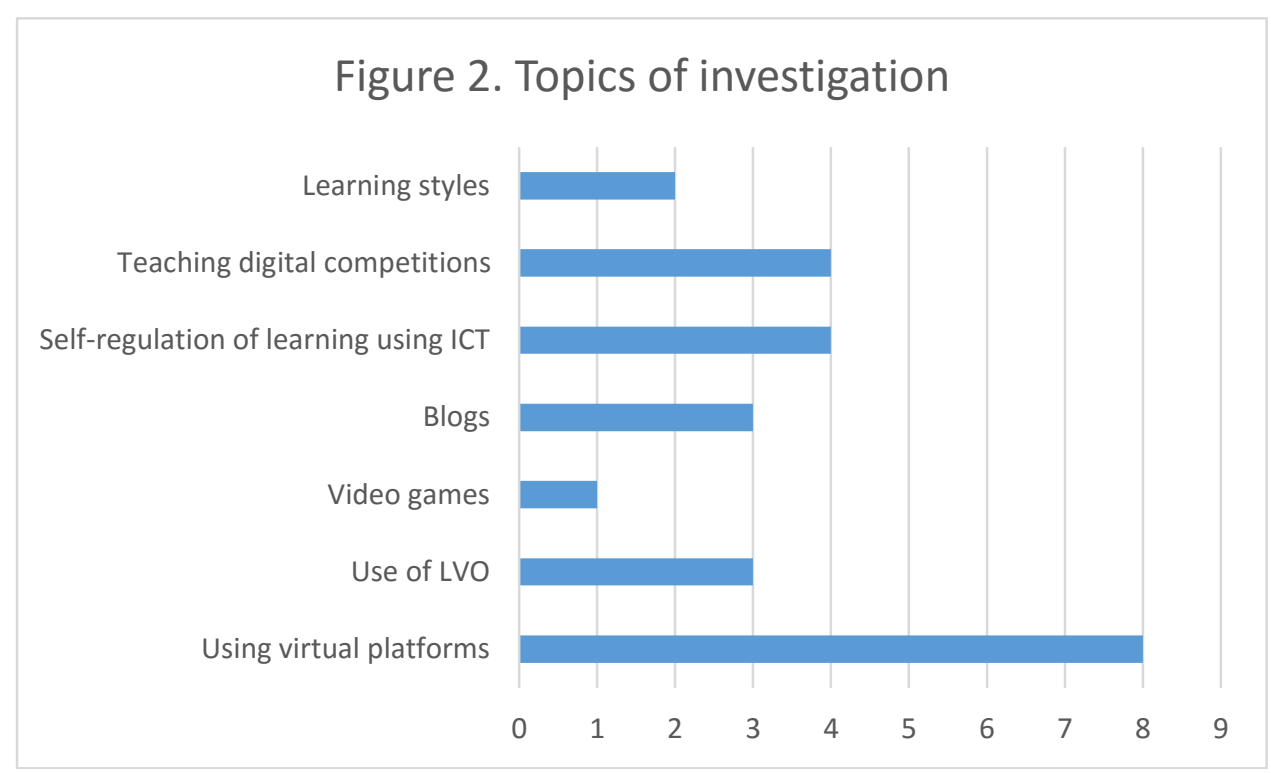

Font: The authors 
In the third place, the research objectives. In this category, three sub categories were identified: i) To analyze the results of the implementation of the use of virtual platforms, ii) To analyze the impact of ICT in different contexts, and iii) To analyze the teacher's competences in digital tools. This indicates the rise and offer of educational platforms that are used as support even for face-to-face and seek to strengthen digital skills both in teachers and students who use them. The previous results show that pedagogical innovations are important to have in mind when investigating. The results are shown in figure 3 .

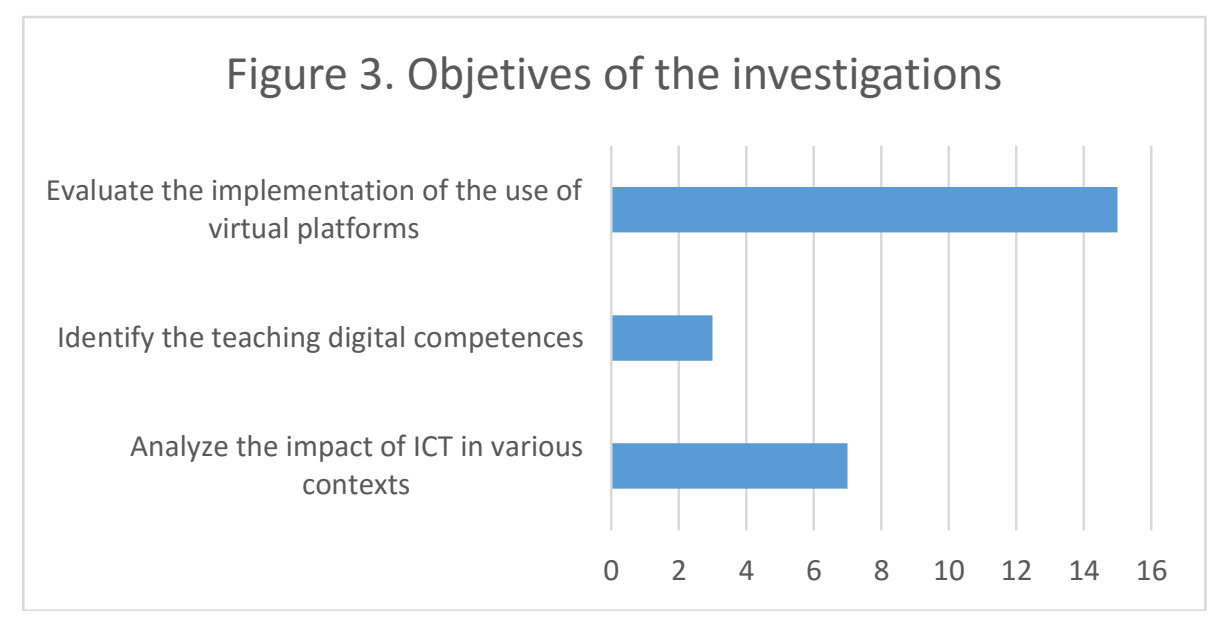

Font: The authors.

According to the support theories used by students, it can be seen that constructivism is the most used, followed by gamification and self-regulation of learning, which coincides with the approaches reviewed by the literature, and evidence that the master's degree discusses on the issues that technological inclusion demands for new generations. However, it is possible to observe a variety in the lines (up to a total of 7 applications), which can be seen as an example of the relationship between ICTs and the development methods of education theory. It means that once again Educational innovations are an important issue to take the theory into account when investigating. The results are seen in figure 4. 


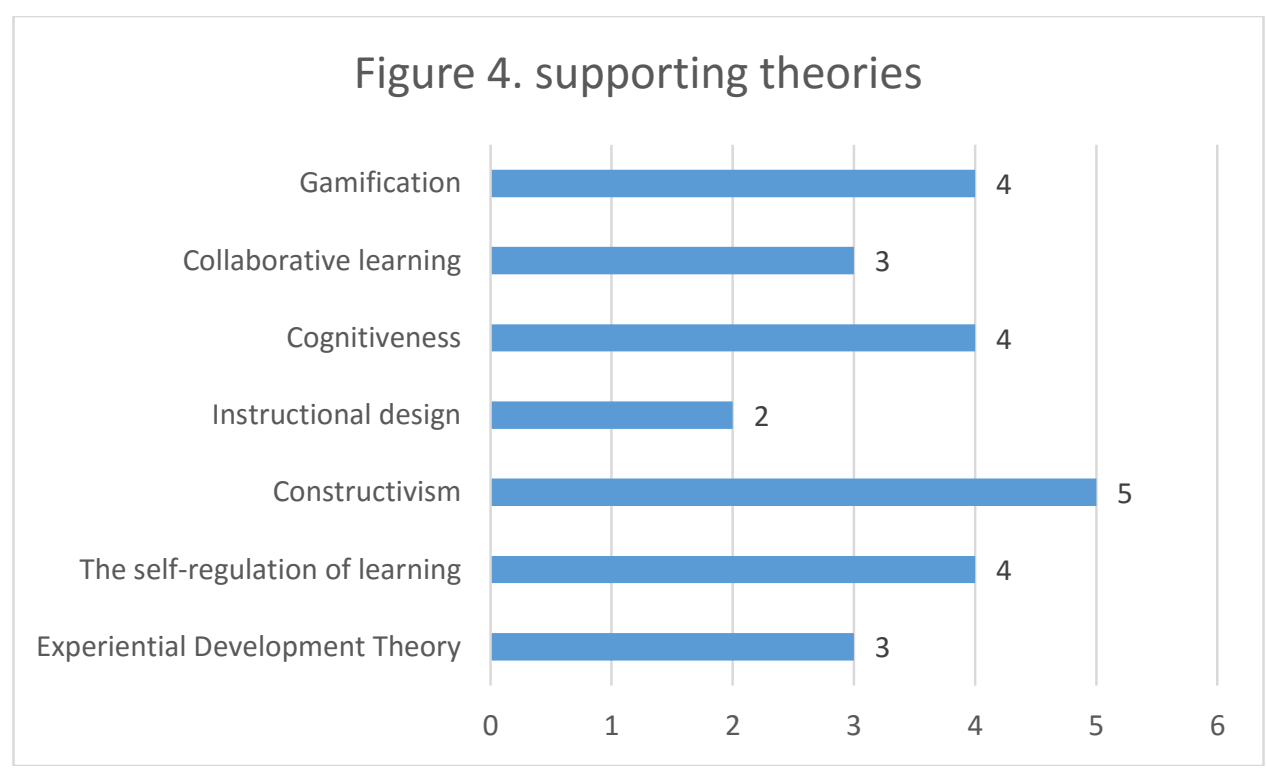

Font: The authors

Regarding the impact generated by the projects, the development of teaching programs and methodologies is recognized as the main effect of the teachers' work, followed by the use of virtual support tools and the consolidation of collaborative learning. This clearly shows how the development of research in Colombia is geared towards the challenges of change in educational processes with ICT as an instrument and means that promotes new teaching-learning processes in the academic community. In this category, the Pedagogical Innovations have the greatest result as far as impact is concerned. However, integrated and communication strategies and selfmanagement are Educational Innovation that were taken into account to analyze this category but they had less approval in the works. The result summary is seen in Figure 5.

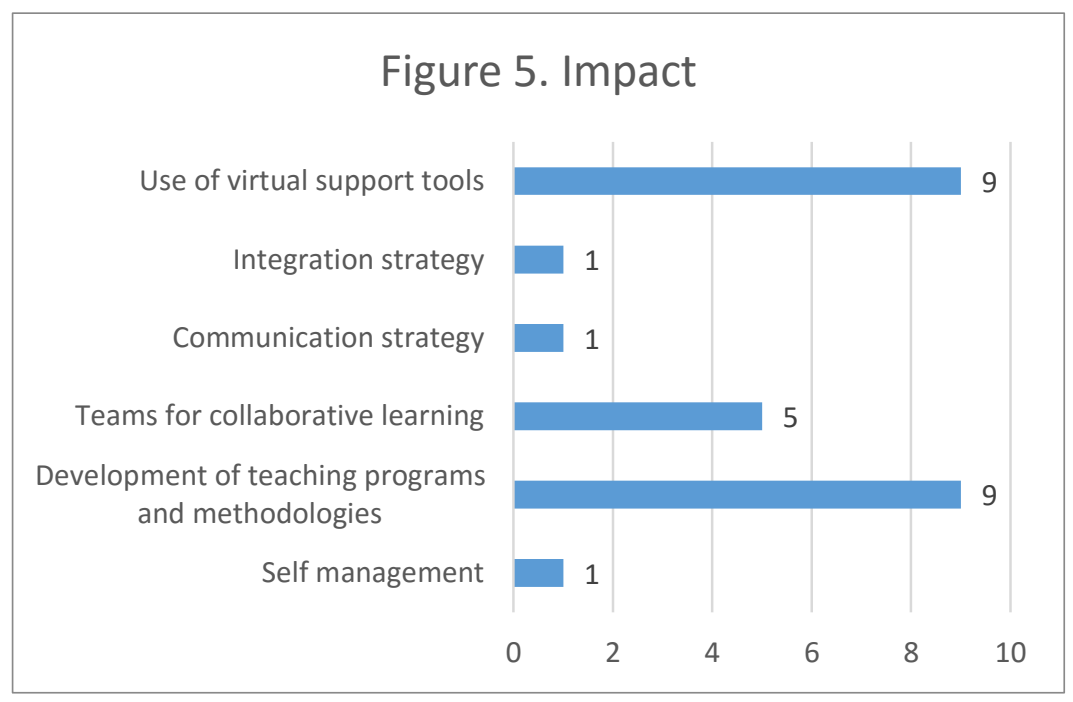

Font: The authors 
Once the categories were analyzed, some of the main contributions were highlighted. For greater understanding, the most relevant characteristics of each one are stand out.

The learning styles related to collaborative learning influence the individual and group performance of the students; so, to know the characteristics of each one allows the creation of a more active and reflective work teams with a greater empowerment of the activity that performed; this way, apathetic, associable and hermetic behaviors are avoiding. This is seen both in study groups for the use of technology, as well as in teaching practices to facilitate the teaching and linking of the actors of the academic community through the platform to work the integrality.

It is clear for these practices that the psychological and communicative competences are the ones that have the most influence in the teaching and learning process in virtual environments in order to help the students interaction, accompaniment and motivation required and thus achieve success in their academic performance demonstrating how technology is immersed in the daily processes of the academic community.

Regarding to the integration of ICT in the classroom, teachers agree that they use technological tools in their practices as a complement and reinforcement of the teaching process and recognize its importance as a resource within this process. Thus, they affirm that it facilitates the possibility of capturing the students' attention in a better way when obtaining proposals in a language that is easier for them to incorporate and allows them to give better results. The examples are varied and can be seen in the learning of languages, in the reflections of different subjects and, in general, they show a good result as long as they have adequate teaching support.

In parallel, the analysis allows evidence that the teacher can show that his teachings have intervened in the student's actions through extracurricular observation. If a student improves the quality of their academic work, a process of efficiency is evident in the accompaniment of the teacher in their learning.

It is possible to anticipate that this topic can be worked more deeply than these practices and the efficiency achieved can be reflected in aspects related to motivation and interaction, which are considered transcendental in the teaching-learning process in a virtual study modality where the orientation, support and guidance work of the student should be highlighted in the tutor, and especially the empathy to be able to direct the work of the young people to achieve the objectives of achievement of planned skills.

Another interesting result is that the implementation of ICTs is accompanied by the development of projects and programs for their use, as well as relevant methodologies that update teaching work and learning processes, and this is a kind of capacity that is implemented in the institutions, which allows them to continue growing according to the new challenges, needs and opportunities of the community.

Talking about negative effects, two aspects are recognized with the analysis; the first, is the challenge for students to see the use of ICT as a learning exercise and not as banal issue, but the observations made allow us to state that students are able to differentiate the use of ICT for learning and entertainment. Teachers value them because they are aware that technology is the language that young people use, but they also promote it as a tool for learning and for personal growth and that they are complemented by self-management by the community, this being a favorable aspect. for the current dynamics of society. 
Another risk that can be analyzed is the cyber bullying -once the related works allowed us to see the negative effects of this phenomenon- such as depression and fear, where young people express their concern about these issues and make it a practice that should be incorporated by teachers to obtain the expected results and help students grow.

Finally, the work allows us to see that teachers need to deepen their knowledge in the development of ICT skills, to provide a quality and relevant education, which allows them to be creative and purposeful in the planning and design of dynamic and interactive environments, which contributing to the teaching, learning and evaluation process.

It is important to highlight that both: Pedagogical Innovations and Educational Innovations has been important issues to have into account when students of the Master in Education of Virtual and Distance Uniminuto start working on their research jobs and these issues has impacted the teaching, learning and evaluation process in this educational context

\section{Results}

With the incursion of technology and its use and appropriation in education, the transformation towards digital is ongoing. This $21^{\text {st }}$ century advances rapidly and technology evolves, too. "The uses of ICT in education can favor teaching and learning processes oriented towards the construction of meaningful learning" (Valencia et al. P. 9). The curriculum and the teacher must change and it is important to think that he is training professionals for nonconventional jobs different from those that are known, which means that innovation is required in the approach of the curriculum, in addition to its flexibility and internationalization. This has to go hand in hand with a permanent training and updating of teachers in pedagogy, didactics, technology and evaluation, among others, so that pedagogical innovation and significant student learning can be promoted.

Investigating the use and appropriation of information technologies in the educational field has gained relevance due to the progress and evolution of the digital. The works analyzed showed a particular interest in addressing these issues at the different levels and modalities of education that show how the inspiration of ICTs favors student learning.

The training of teachers plays an important role in the development of teaching, learning and evaluation processes when it comes to using technology, since their willingness and willingness are required to carry out projects that involve technology. By testing it with their students, environments are created in which they share and strengthen competencies such as collaborative work and effective communication.

It is pertinent to attend that the investigations of the students of the Master in Education at UNIMINUTO Virtual and Distance contemplate innovation, either pedagogical or educational as part of the necessary change for the transformation of ICT research, these investigations offer studies which refer to the challenges presented by teachers, students and the educational community in general in relation to the issues related to the changes that new technologies bring about in pedagogical matters.

Finally, it is important to clarify that innovation in pedagogical training is a continuous cycle, which points to the virtue of teachers and students in mutual learning that goes hand in hand with the need for change in favor of new forms of education. 
As the main contribution to knowledge management, this analysis of qualitative studies of the use of ICT in educational environments represents a sample of an efficient and effective use of technology at the service of education, in the way that it is used and becomes ally of the teaching, learning and evaluation process. The interest to investigate this thematic and growing and advances as the same technology does, more and more the digital permeates education, where the figure of the teacher as mediator of the process is fundamental to achieve significant learning.

\section{References}

Aguiar, B. O., Velázquez, R., \& Aguiar, J. (2019). Innovación docente y empleo de las TIC en la Educacion Superior. Revista ESPACIOS, 40(2), 8-30. Retrieved from https://www.revistaespacios.com/a19v40n02/19400208.html

Bates, A. (2017). La enseñanza en la era digital. Una guía para la enseñanza y el aprendizaje. Canadá: Asociación de Investigación Contact North., Recuperado de http://www.tonybates.ca/2017/02/04/a-spanish-version-of-teaching-in-a-digital-age-is-nowavailable/

Boltanski, L., \& Chiapello, E. (2002). El nuevo espíritu del capitalismo/ The New Spirit of Capitalism (Cuestiones De Antagonismo / Questions of Antagonism). Madrid: Akal Ediciones.

Carbonell, J. (2002). El profesorado y la innovación educativa. En La Innovación educativa, Cañal de León Pedro (coord.). Akal ediciones, Madrid, España:11-26

Castillo, V. (2017). La formación pedagógica del docente universitario. Palermo Business Review, (16), 65-73. Recuperado de https://search-proquestcom.ezproxy.uniminuto.edu/docview/2080197389?accountid=48797

Chesbrough, H. (2015). Innovación abierta. Innovar con éxito en el siglo XXI. Reinventar la empresa en la era digital.

Cobo, C. (2016). La innovación pendiente. Reflexiones (y provocaciones) sobre educación, tecnología y conocimiento. Colección Fundación Ceibal. Montevideo: Debate.

Fundación Telefónica. (2016). Innovaciones educativas 2016. Educar para la sociedad digital. Madrid: Fundación Telefónica.

González, H., \& Ospina, H. (2015). Interacciones entre universidad y sociedad: contextos para pensar la educación contemporánea. Revista Virtual Universidad Católica Del Norte, 44.

López, L. (2008). University professor: a contemporary view. Revista de La Facultad de Ciencias Económicas, XVI(1), 23-40.

Núñez, C., Gaviria-Serrano, J. M., Tobón, S., Guzmán-Calderón, C. E., \& Herrera, S. R. (2019). La práctica docente mediada por TIC: una construcción de significados. Espacios, 40(5).

Pozos Pérez, K. V., \& Tejada Fernández, J. (2018). Competencias Digitales en Docentes de Educación Superior: Niveles de Dominio y Necesidades Formativas. Revista Digital de Investigación En Docencia Universitaria, 12(2), 59-87. Recuperado de https://doi.org/10.19083/ridu.2018.712

Tébar, L. (2016). La función mediadora de la educación. Revista de la Universidad de La Salle, 70, 13-32. 
Valencia, T., Serna, A., Ochoa, S., Caicedo, A., Montes, J. y Chávez, J. (2016). Competencias y estándares TIC desde la dimensión pedagógica: una perspectiva desde los niveles de apropiación de las TIC en la práctica educativa docente Cali: Pontificia Universidad Javeriana. 